\title{
Stimulated and Non-Stimulated Salivary Flows Should be Tested for the Presence of HCV RNA in Saliva Samples from Patients with Chronic Hepatitis C
}

\author{
Grossmann SMC ${ }^{1,4^{*}}$, De Oliveira GC $^{2}$, Teixeira $\mathbf{R}^{3}$ and Vieira do Carmo MA ${ }^{1}$ \\ ${ }^{1}$ Department of Oral Surgery and Pathology, School of Dentistry, Universidade Federal de Minas Gerais, Belo Horizonte, Brazil \\ ${ }^{2}$ René Rachou Fiocruz Research Centre, Belo Horizonte, Minas Gerais, Brazil \\ ${ }^{3}$ Department of Medical Clinic, School of Medicine, Universidade Federal de Minas Gerais, Belo Horizonte, Brazil \\ ${ }^{4}$ Department of Oral Diagnosis, School of Dentistry, Universidade Vale do Rio Verde, Belo Horizonte, Brazil
}

*Corresponding author: Soraya de Mattos Camargo Grossmann, Universidade Vale do Rio Verde, Faculdade de Odontologia, Rua Gentios, 1420 - Luxemburgo, Belo Horizonte - CEP: 37410-000, Minas Gerais, Brazil, Tel: + 55-31-33441366; E-mail: sogrossmann@uol.com.br

Rec date: Feb 26, 2014, Acc date: Apr 18, 2014, Pub date: Apr 20, 2014

Copyright: (c) 2014 Grossmann SMC, et al. This is an open-access article distributed under the terms of the Creative Commons Attribution License, which permits unrestricted use, distribution, and reproduction in any medium, provided the original author and source are credited.

\begin{abstract}
Objective: In most of the studies which analyzed the presence of HCV RNA in saliva from patients with chronic Hepatitis C only stimulated saliva samples have been used for viral detection. Thus, this study compared the prevalence of HCV RNA in non-stimulated and stimulated salivary flows in patients with chronic Hepatitis C.

Design: Saliva samples of non-stimulated and stimulated salivary flows from 24 patients were collected, and the HCV RNA was investigated by RT-nested PCR. Data regarding age, gender, risk factors for HCV infection, xerostomia and hyposalivation were also analyzed.

Results: The HCV RNA could be detected in 11 (45.8\%) non-stimulated and in 14 (58.3\%) stimulated saliva samples, without statistical significance $(p=0.472)$. However, in $18(75.0 \%)$ patients it was possible to detect the presence of the HCV RNA at least in one of the saliva samples. Six $(25.0 \%)$ patients complained of xerostomia and nine $(37.5 \%)$ presented hyposalivation, but in only $3(12.5 \%)$ patients, these conditions could be observed, simultaneously. No significant correlation between the presence of HCV RNA in saliva and age, gender, risk factors for HCV infection, xerostomia and hyposalivation could be identified.
\end{abstract}

Conclusion: Both stimulated and non-stimulated saliva samples must be investigated for the presence of HCV RNA in patients with chronic Hepatitis $\mathrm{C}$, to avoid underestimated prevalence of $\mathrm{HCV}$ in this group of patients.

Keywords: HCV RNA; Saliva; Chronic Hepatitis C; HCV

\section{Introduction}

Hepatitis C Virus (HCV) infection is a major cause of chronic liver disease and liver-related morbidity and mortality worldwide and it is the most prevalent reason for liver transplants in Europe and in the USA [1].

Up to $74 \%$ of the HCV-infected patients may develop at least one Extra Hepatic Manifestation (EHM) during the course of the infection, such as salivary gland disorders, being the HCV considered as a sialotropic virus [2-6]. The reported prevalence of the HCV RNA in saliva ranges from 0 to $100 \%[7,8]$. In a recent study conducted with Brazilian patients, Grossmann et al. [9] detected the HCV RNA in $39.0 \%$ of the non-stimulated saliva samples in patients with serum positive HCV RNA. These discrepancies may be due to the heterogeneity of the study design, population studied as well as different methodologies used as saliva sampling methods.

Xerostomia in patients with chronic Hepatitis $\mathrm{C}$ ranges from 10 to $20 \%[2,10]$ and its association with an objective evidence of salivary gland dysfunction like hyposalivation has been described in previous literature $[11,12]$. It has been suggested that whole saliva could be used as a screening test for identifying a suspected exocrine hypofunction and an abnormality in the salivary gland, such as the Sjögren Syndrome [13].

As the prevalence of $\mathrm{HCV}$ in saliva samples shows important differences among the studies, and most of them analyze only stimulated salivary flows $[11,14]$, the aim of this study was to compare the prevalence of HCV RNA in saliva samples between non stimulated and stimulated salivary flows in a group of patients with chronic Hepatitis C. The possible association with xerostomia and presence of hyposalivation were also evaluated.

\section{Patients and Methods}

\section{Patients}

A cross-sectional survey was carried out on $24 \mathrm{HCV}$ patients with confirmed diagnosis of chronic Hepatitis C (anti-HCV positive, Elisa III, HCV RNA qualitative test positive) admitted to the Viral Hepatitis Reference Center of the Alfa Institute of Gastroenterology at the Clinical Hospital of Universidade Federal de Minas Gerais (AHEV/ IAG-HC/UFMG), Belo Horizonte, Brazil. The study was approved by the UFMG Ethical Committee for Surveys, and all volunteers signed an informed consent form. All patients were HIV (human immunodeficiency virus) and HBV (Hepatitis B virus) negative and had no other concomitant liver diseases. Patients receiving antiviral 
Citation: Grossmann SMC, De Oliveira GC, Teixeira R, Vieira do Carmo MA (2014) Stimulated and Non-Stimulated Salivary Flows Should be Tested for the Presence of HCV RNA in Saliva Samples from Patients with Chronic Hepatitis C. Dentistry 4: 232. doi: $10.4172 / 2161-1122.1000232$

Page 2 of 5

treatment for Hepatitis C were also excluded from the study. Demographical data as well as risk factors for the acquisition of the infection were assessed from medical records. Intra-oral examination was performed on all patients.

\section{Xerostomia}

Patients were inquired in relation to symptom of dry mouth (xerostomia). If present, xerostomia was classified as mild, moderate, or severe, as previously described [4] and the patients received treatment with artificial saliva gel (Oral Balance- Biotene') to relieve their symptom.

\section{Saliva samples}

Patients refrained from oral hygiene, eating, drinking, and smoking 60 min before non-stimulated (NSSF) and stimulated (SSF) salivary collection in sterile $50 \mathrm{~mL}$ Falcon tubes. The entire NSSF produced during three minutes was collected. Rates $\leq 0.1 \mathrm{ml} / \mathrm{min}$ was considered hyposalivation, as previously established [15]. Subsequently, patients were asked to chew a sterile rubber cylinder for three minutes before spitting saliva to measure SSF. Rates of $\leq 0.7 \mathrm{ml} / \mathrm{min}$ were considered as hyposalivation [15]. All saliva samples were immediately stored at $80^{\circ} \mathrm{C}$.

\section{Detection of HCV RNA in the saliva}

HCV RNA was extracted from $200 \mu \mathrm{L}$ of undiluted saliva using a commercial viral RNA isolation kit (Qiaamp, Qiagem, Hildem Germany), according to manufacturer's instructions. Nested reverse transcription-polymerase chain reaction (RT-PCR) was performed, by amplification of a $251 \mathrm{bp}$ fragment from the 5' UTR region of HCV with a minor adaptation described by Oliveira et al. [16]. Briefly, a single-strand cDNA was synthesized from $18 \mu \mathrm{L}$ of the RNA sample at $42^{\circ} \mathrm{C}$ for 50 minutes with $200 \mathrm{U}$ of reverse transcriptase (Superscript II, GIBCO, BRL, Rockville, MD, USA) in $30 \mu \mathrm{L}$ of a manufacturer supplied buffer containing 10 pmole of primer 209 (ATACTCGAGGTGCACGGGTCTACGAGACCT), $10 \mathrm{mM}$ of each $\mathrm{dNTP}$, and $10 \mathrm{nM}$ of dithiothreitol. For the first-round of PCR, $2 \mu \mathrm{L}$ of cDNA were added to a mixture containing $2 \mu$ of $10 x$ of the supplied PCR buffer, $5 \mathrm{mM}$ of $\mathrm{MgCl} 2,10 \mathrm{mM}$ of each dNTP, 10 pmole of primers 939 (CTGTGAGGAACTACTGTCTT) and 209, and 5U of Taq DNA polymerase (GIBCO/ BRL). The mixture was cycled 30x in a thermocycler (Perkin Elmer Gene Amp PCR System 2400) at $95^{\circ} \mathrm{C}$ for 5 minutes, $95^{\circ} \mathrm{C}$ for 1 minute, $50^{\circ} \mathrm{C}$ for 1 minute, $72^{\circ} \mathrm{C}$ for 1 minute, and again at $72^{\circ} \mathrm{C}$ for 1 minute. The second-round of PCR (nested) was carried out as above, using primers 940 (TTCACGCAGAAAGGGTCTAG) and 211 (CACTCTCGGAGCACCCTATCAGGCAGT) as well as $1.5 \mathrm{U}$ of Taq polymerase. The PCR products were electrophoresed in a $6 \%$ polyacrylamide gel, using a vertical electrophoresis apparatus (Model S2 Life Technologies Inc.) and stained with silver nitrate. The banding pattern was visualized and analyzed as described by McOmish [17]. A known HCV RNA positive saliva sample was used as a positive control and, to a negative control, viral RNA was omitted.

\section{Statistical analysis}

Chi-square and Fisher's tests were used for univariate analysis. $\mathrm{p}$ value $\leq 0.05$ was considered significant.

\section{Results}

The group studied consisted of 13 (54.2\%) females and 11 (45.8\%) males, with a mean age of 52.4 years and median of 52 years (range 29-73 years of age). Main sources of infection included blood transfusions in 10 (41.7\%) cases and intravenous drug use in $4(16.7 \%)$ cases. Risk factors could not be identified in $4(16.7 \%)$ patients (Table $1)$.

\begin{tabular}{|c|c|c|c|c|c|c|}
\hline & \multicolumn{3}{|c|}{$\begin{array}{l}\text { HCV RNA in non- } \\
\text { stimulated salivary flow }\end{array}$} & \multicolumn{3}{|c|}{$\begin{array}{l}\text { HCV RNA in stimulated } \\
\text { salivary flow }\end{array}$} \\
\hline & $\begin{array}{l}\text { Positive } \\
n(\%)\end{array}$ & $\begin{array}{l}\text { Negative } \\
n(\%)\end{array}$ & $\mathrm{p}$ & $\begin{array}{l}\text { Positive } \\
n(\%)\end{array}$ & $\begin{array}{l}\text { Negative } \\
n(\%)\end{array}$ & $\mathrm{p}$ \\
\hline Gender & & & 0.115 & & & 0.184 \\
\hline Female & $4(36.4)$ & $9(69.2)$ & & $6(42.9)$ & $7(70.0)$ & \\
\hline Male & $7(63.6)$ & $4(30.8)$ & & $8(57.1)$ & $3(30.0)$ & \\
\hline Age & & & 0.646 & & & 0.239 \\
\hline$\leq 52$ years old & $6(36.4)$ & $7(69.2)$ & & $6(42.9)$ & $7(70.0)$ & \\
\hline$>52$ years old & $5(63.6)$ & $6(30.8)$ & & $8(57.1)$ & $3(30.0)$ & \\
\hline Risk Factors & & & 0.121 & & & 0.241 \\
\hline $\begin{array}{l}\text { Blood } \\
\text { transfusion }\end{array}$ & $4(36,4)$ & $6(46,2)$ & & $5(35.7)$ & $5(50.0)$ & \\
\hline i.v. drug use & $3(27,3)$ & $1(7,7)$ & & $3(21.4)$ & $1(10.0)$ & \\
\hline $\begin{array}{l}\text { Percutaneous } \\
\text { exposure }\end{array}$ & $2(18,2)$ & $0(0,0)$ & & $1(7.1)$ & $1(10.0)$ & \\
\hline Others & $0(0,0)$ & $4(30,8)$ & & $4(28.6)$ & $0(0.0)$ & \\
\hline Unknown & $2(18,2)$ & $2(15,4)$ & & $1(7.1)$ & $3(30.0)$ & \\
\hline
\end{tabular}

Table 1: Prevalence of HCV RNA in saliva, according to gender and risk factors

\begin{tabular}{|l|l|l|l|l|}
\hline \multirow{2}{*}{$\begin{array}{l}\text { HCV RNA in stimulated } \\
\text { salivary flow }\end{array}$} & \multicolumn{4}{|l|}{ HCV RNA in non-stimulated salivary flow } \\
\cline { 2 - 5 } & $\begin{array}{l}\text { Positive } \\
\mathrm{n}(\%)\end{array}$ & $\begin{array}{l}\text { Negative } \\
\mathrm{n}(\%)\end{array}$ & $\begin{array}{l}\text { Total } \mathrm{n} \\
(\%)\end{array}$ & $\mathrm{p}$ \\
\hline Positive $\mathrm{n}(\%)$ & $7(63.6)$ & $7(53.8)$ & $14(100.0)$ & 0.472 \\
\hline Negative $\mathrm{n}(\%)$ & $4(45.8)$ & $6(46.2)$ & $10(100.0)$ & \\
\hline Total $\mathrm{n}(\%)$ & $\begin{array}{l}11 \\
(100.0)\end{array}$ & $13(100.0)$ & $24(100.0)$ & \\
\hline $\begin{array}{l}\text { Fisher's exact test } \\
\text { Legend: } \mathrm{n} \text { - absolute number; (\%) - relative number }\end{array}$ \\
\hline
\end{tabular}

Table 2: Correlation between the prevalence of HCV RNA in stimulated and non-stimulated salivary flows

HCV RNA was detected in non-stimulated saliva samples of 11 (45.8\%) patients (4 women and 7 men) and in stimulated saliva samples of $14(58.3 \%)$ patients (6 women and 8 men), with no 
Citation: Grossmann SMC, De Oliveira GC, Teixeira R, Vieira do Carmo MA (2014) Stimulated and Non-Stimulated Salivary Flows Should be Tested for the Presence of HCV RNA in Saliva Samples from Patients with Chronic Hepatitis C. Dentistry 4: 232. doi: $10.4172 / 2161-1122.1000232$

Page 3 of 5

statistical difference $(\mathrm{p}=0.472)$ (Table 2$)$. In only 7 (29.2\%) patients the HCV RNA could be detected in both, NSSF and SSF, simultaneously. However, in 18 (75.0\%) patients it was possible to detect the presence of the HCV RNA at least in one of the saliva samples.

\begin{tabular}{|l|l|l|l|l|l|l|}
\hline \multirow{2}{*}{$\begin{array}{l}\text { Xerostomi } \\
\text { a }\end{array}$} & \multicolumn{3}{|l|}{ Non stimulated salivary flow } & \multicolumn{3}{l|}{ Stimulated salivary flow } \\
\cline { 2 - 6 } & $\begin{array}{l}\text { Normal } \\
n(\%)\end{array}$ & $\begin{array}{l}\text { Hyposalivation } \\
n(\%)\end{array}$ & $\mathrm{p}$ & $\begin{array}{l}\text { Normal } \\
n(\%)\end{array}$ & $\begin{array}{l}\text { Hyposalivation } \\
n(\%)\end{array}$ & $\mathrm{p}$ \\
\hline Present & $\begin{array}{l}5 \\
(33.3)\end{array}$ & $1(11.1)$ & & $\begin{array}{l}4 \\
(25.0)\end{array}$ & $2(25.0)$ & 0.68 \\
\cline { 5 - 7 } & $\begin{array}{l}10 \\
\text { Absent }\end{array}$ & $8(88.9)$ & 7 & $\begin{array}{l}12 \\
(75.0)\end{array}$ & $6(75.0)$ & 0 \\
\hline Total $\mathrm{n}(\%)$ & $\begin{array}{l}15 \\
(100.0)\end{array}$ & $9(100.0)$ & & $\begin{array}{l}16 \\
(100.0)\end{array}$ & $8(100.0)$ & \\
\hline $\begin{array}{l}\text { Fisher's exact test } \\
\text { Legend: } \mathrm{n} \text { - absolute number; (\%) - relative number }\end{array}$ \\
\hline
\end{tabular}

Table 3: Correlation between the prevalence of xerostomia and hyposalivation and salivary flows

Six (25.0\%) patients complained of oral dryness (xerostomia) which was mild in $4(16.7 \%)$ patients, and moderate in $2(8.3 \%)$ cases. Considering the entire sample, hyposalivation could be observed in 9
(37.5\%) cases of non-stimulated salivary flow and in 8 (33.3\%) cases of stimulated salivary flow. However, in only $3(12.5 \%)$ cases the xerostomia and hyposalivation could be observed, simultaneously (Table 3).

Among the patients with xerostomia and hyposalivation, in both different flows, the HCV could be detected more frequently in saliva sample from non-stimulated salivary flow (6 cases) (Table 4 ).

Oral mucosal alterations, including variations of normality and mucosal lesions were observed in 20 (83.3\%) patients. The most common alterations were traumatic lesions in 8 (33.4\%) cases, followed by Fordyce's spots in $6(25.0 \%)$ cases, and candidiasis in 4 $(16.7 \%)$ cases.

\section{Discussion}

As Hepatitis $\mathrm{C}$ is often asymptomatic or shows no specific manifestation in the acute phase, the WHO estimates that there are millions of undiagnosed HCV-infected people, constituting an important link in the chain of HCV transmission [18]. Thus, the recognition of extra Hepatic manifestations of this infection is considered of great importance regarding the establishment of an early diagnosis.

\begin{tabular}{|c|c|c|c|c|c|c|}
\hline & \multicolumn{3}{|c|}{ HCV RNA in non-stimulated salivary flow } & \multicolumn{3}{|c|}{ HCV RNA in stimulated salivary flow } \\
\hline & $\begin{array}{l}\text { Positive } \\
n(\%)\end{array}$ & $\begin{array}{l}\text { Negative } \\
n(\%)\end{array}$ & $\mathrm{p}$ & $\begin{array}{l}\text { Positive } \\
n(\%)\end{array}$ & $\begin{array}{l}\text { Negative } \\
n(\%)\end{array}$ & $\mathrm{p}$ \\
\hline Xerostomia & $3(27.3)$ & & 0.589 & & & 0.494 \\
\hline Present & $8(72.7)$ & $3(23.1)$ & & $3(21.4)$ & $3(30.0)$ & \\
\hline Absent & & $10(76.9)$ & & $11(78.6)$ & $7(70.0)$ & \\
\hline Non Stimulated Salivary Flow & $8(72.7)$ & & 0.300 & & & 0.418 \\
\hline Normal & $3(27.3)$ & $7(53.8)$ & & $8(57.1)$ & $7(70.0)$ & \\
\hline Hyposalivation & & $6(46.2)$ & & $6(42.9)$ & $3(30.0)$ & \\
\hline Stimulated Salivary Flow & $7(63.6)$ & & 0.555 & & & 0.438 \\
\hline Normal & $4(36.4)$ & $9(69.2)$ & & $10(71.4)$ & $6(60.0)$ & \\
\hline Hyposalivation & & $4(30.8)$ & & $4(28.6)$ & $4(40.0)$ & \\
\hline Total & $11(45.8)$ & $13(54.2)$ & & $14(58.3)$ & $10(41.7)$ & \\
\hline \multicolumn{7}{|l|}{ Fisher's exact test } \\
\hline
\end{tabular}

Table 4: Prevalence of HCV RNA in relation to the presence of xerostomia and hyposalivation in stimulated and non-stimulated salivary flows

As expected, the main source of transmission of HCV in the present study was blood transfusion (41.7\%), which is in accordance with that reported in the literature [1]. Besides, in 4 patients (16.7\%), the source of infection was unknown, in accordance with our previous study $[9,19,20]$.

Considering the reported sialotropism of $\mathrm{HCV}$, with different findings, and taking into account that most of the studies used only stimulated salivary flow, the present study aimed to compare the prevalence of HCV RNA in saliva samples from non-stimulated and stimulated salivary flows. Our results showed the presence of $\mathrm{HCV}$ RNA in non-stimulated and stimulated saliva samples in 11 patients $(45.8 \%)$ and in 14 patients (58.3\%), respectively, with no statistically significant difference $(\mathrm{p}=0.472)$. These findings suggest that both nonstimulated and stimulated saliva samples are equally suitable for the investigation of the presence of salivary HCV RNA. In only 7 (29.2\%) 
Citation: Grossmann SMC, De Oliveira GC, Teixeira R, Vieira do Carmo MA (2014) Stimulated and Non-Stimulated Salivary Flows Should be Tested for the Presence of HCV RNA in Saliva Samples from Patients with Chronic Hepatitis C. Dentistry 4: 232. doi: $10.4172 / 2161-1122.1000232$

Page 4 of 5

patients the HCV RNA could be detected in both, NSSF and SSF, simultaneously. However, a very higher prevalence could be observed in $18(75.0 \%)$ patients in whom it was possible to detect the presence of the HCV RNA at least in one of the saliva samples. We consider this as an important finding that points toward the necessity of investigation the presence of HCV RNA in both salivary flows, taking into account that the mechanism of viral shedding is not wellunderstood. It is also necessary to emphasize that a more representative sample to determinate the real prevalence of HCV RNA in saliva is warranted.

Some authors reported that there is no correlation between the presence of anti-HCV antibodies in saliva and the detection of HCV RNA in saliva and salivary glands in patients with chronic Hepatitis $\mathrm{C}$ [21]. However, others suggested that the salivary HCV viral load is significantly lower than the viral load in the serum16, and this could explain the controversial results that investigate the HCV in saliva in patients with chronic Hepatitis C.

No significant correlations were found between the presence of HCV RNA in non-stimulated or stimulated saliva samples and age, gender, risk factors, xerostomia, or hyposativation in accordance with previous study [9]. We consider that the xerostomia and hyposalivation in Hepatitis $\mathrm{C}$ patients is not association with direct detection of HCV in saliva. We results suggest that an indirect effect as more inflammatory cells in salivary gland (PATRICIA) could be responsible for xerostomia and hyposalivation in this group of patients.

In the present study, six (25.0\%) patients complained of oral dryness (xerostomia) and hyposalivation could be identified in 9 $(37.5 \%)$ patiens, with no statistical significance. Dry mouth (xerostomia) has been reported in 0 to $35 \%$ patients with chronic Hepatitis C $[2,5,11,14]$. Some authors have the HCV as a virus with a triple tropism (Hepatotropism, lymphotropism, and sialotropism), which could explain the xerostomia in these patients [14]. In addition, the reduced salivary flow rate (hyposalivation) in Hepatitis $\mathrm{C}$ patients could be due to infiltration of the salivary gland by the virus [12] or to a possible virus induced immune mechanism [22,23]. However, in only 3 cases (12.5\%) xerostomia and hyposalivation were observed, simultaneosly. Moreover, in 9 of 10 patients without xerostomia, the hyposalivation was also detected. In these patients could not to demonstrate the association between xerostomia and use of medication. As xerostomia is a subject symptom and hyposalivation is an objective find, thus we consider that this association should be more investigate. Despite the small sample, our results agree with those obtained by Henderson et al. [11] and Ferreiro et al. [14], who found a weak association between xerostomia and hyposalivation. Further research to elucidate this point is needed.

Oral mucosal alterations were observed in almost all evaluated patients with chronic Hepatitis C (83.3\%) as in our previous study [20]. Due to the high global prevalence of chronic Hepatitis C, and the potential association between oral lichen planus and chronic Hepatitis C [19], we consider important periodic oral examination in order to promote the suitable and full health assistance to these patients.

Although in stimulated and non-stimulated salivary flows it is possible the detection of HCV RNA, and regardless the small sample, our findings strongly suggest that the investigation should be performed in both samples, to avoid bias regarding the real prevalence of this virus in saliva of patients with chronic Hepatitis C. Moreover, the detection of HCV RNA in saliva cannot determine definitively a direct effect of this virus in presence of xerostomia and hyposalivation in Hepatitis $\mathrm{C}$ patients. Thus, investigations that try elucidating the possible sialotropism of $\mathrm{HCV}$ are necessary.

\section{Acknowledgements}

This study was supported by grants from CAPES (Coordenação de Aperfeiçoamento de Pessoal de Nível Superior), FAPEMIG (Fundação de Amparo à Pesquisa do Estado de Minas Gerais) and $\mathrm{CNPq}$ (Conselho Nacional de Desenvolvimento Científico e Tecnológico National Counsel of Technological and Scientific Development). Dra. Teixeira R and Dr. Oliveira GO are research fellows of CNPq.

\section{References}

1. Ghany MG, Strader DB, Thomas DL, Seeff LB (2009) American Association for the Study of Liver Diseases. Diagnosis, management, and treatment of Hepatitis C: an update. Hepatology 49: 1335-1374.

2. Cacoub P, Renou C, Rosenthal E, Cohen P, Loury I, et al. (2000) ExtraHepatic manifestations associated with Hepatitis $C$ virus infection: a prospective multicenter study of 321 patients. Medicine 79: 47-56.

3. Haddad J, Deny P, Munz-Gotheil C, Ambrosini JC, Trinchet JC, et al. (1992) Lymphocytic sialadenitis of sjogren's syndrome associated with chronic Hepatitis C virus liver disease. Lancet 339: 321-332.

4. Pirisi M, Scott C, Fabris C, Ferraccioli G, Soardo G, et al. (1994) Mild sialoadenitis: a common finding in patients with Hepatitis $\mathrm{C}$ virus infection. Scand J Gastroenterol 29: 940-942.

5. Scott CA, Avellini C, Desinan L, Pirisi M, Ferraccioli GF, et al. (1997) Chronic lymphocytic sialoadenitis in HCV-related chronic liver disease: comparison of Sjögren's Syndrome. Histopathol 30: 41-48.

6. Zignego AL, Craxì A (2008) ExtraHepatic manifestations of Hepatitis C virus infection. Clin Liver Dis 12: 611-636.

7. Fried MW, Shindo M, Fong TL, Fox PC, Hoofnagle JH, et al. (1992) Absence of Hepatitis $\mathrm{C}$ viral RNA from saliva and semen of patients with chronic Hepatitis C. Gastroenterol 102: 1306-1308.

8. Takamatsu K, Koyanagi Y, Okita K, Yamamoto N (1990) Hepatitis C virus in saliva. Lancet 336: 1515.

9. Grossmann SMC, Teixeira R, de Oliveira GC, do Carmo MA (2010) Detection of HCV RNA in saliva does not correlate with salivary flow or xerostomia in patients with chronic Hepatitis C. Oral Surg Oral Med Oral Pathol Oral Radiol Endod 109: 851-856.

10. Ferreiro MC, Prieto MH, Rodríguez SB, Vázquez RL, Iglesias AC, et al. (2002) Whole stimulated salivate flow in patients with chronic Hepatitis C virus infection. J Oral Pathol Med 31: 117-120.

11. Henderson L, Muir M, Mills PR, Spence E, Fox R, et al. (2001) Oral health of patients with HCV infection: a pilot study. Oral Dis 7: 271-275.

12. Mariette X, Loiseau P, Morinet F (1995) Hepatitis C virus in saliva. Ann Intern Med 122: 556.

13. Vitali C, Bombardieri S, Jonsson R, Moutsopoulos HM, Alexander EL, et al. (2002) Classification criteria for Sjögren's syndrome: a revised version of the European criteria proposed by the American-European Consensus Group. Ann Rheum Dis 61: 554-558.

14. Ferreiro MC, Dios PD, Scully C (2005) Transmission of Hepatitis C virus by saliva? Oral Dis 230-235.

15. Jensen SB, Pedersen AM, Reibel J, Nauntfte B (2003) Xerostomia and hypofunction of the salivate glands in cancer therapy. Support Care Cancer 11: 207-225.

16. Oliveira GC, Carmo RA, Rocha MO, Silva MO, Lima AT, et al. (1999) Hepatitis $\mathrm{C}$ virus genotypes in hemophiliacs in the state of Minas Gerais, Brazil. Transfusion 39: 1194-1199.

17. McOmish F, Yap PL, Dow BC, Follet EA, Seed C, et al. (1994) Geographical distribution of Hepatitis $C$ virus genotypes in blood donors: an international collaborative survey. J Clin Microbiol 32: 884-892. 
Citation: Grossmann SMC, De Oliveira GC, Teixeira R, Vieira do Carmo MA (2014) Stimulated and Non-Stimulated Salivary Flows Should be Tested for the Presence of HCV RNA in Saliva Samples from Patients with Chronic Hepatitis C. Dentistry 4: 232. doi: $10.4172 / 2161-1122.1000232$

Page 5 of 5

18. Modi AA, Liang TJ (2008) Hepatitis C: a clinical review. Oral Dis 14: $10-14$.

19. Grossmann SMC, Aguiar MCF, Teixeira R, Carmo MAV (2007) Oral lichen planus and chronic Hepatitis C: a controversial association. Am J Clin Pathol 127: 800-804.

20. Grossmann SMC, Teixeira R, Aguiar MC, de Moura, do Carmo MA, et al. (2009) Oral mucosal conditions in chronic Hepatitis C Brazilian patients: a cross-sectional study. J Public Health Dent 69: 168-175.

21. Caldeira PC, Oliveira E Silva KR, Silva TA, de Mattos Camargo Grossmann S, Teixeira R, et al. (2012) Correlation between salivary anti-
HCV antibodies and HCV RNA in saliva and salivary glands of patients with chronic Hepatitis C. J Oral Pathol Med 42: 222-228.

22. Menezes GB, Pereira FA, Duarte CA, Carmo TM, da Silva Filho HP, et al. (2012) Hepatitis $C$ virus quantification in serum and saliva of HCVinfected patients. Mem Inst Oswaldo Cruz 107: 680-683.

23. Carrozzo M (2008) Oral diseases associated with Hepatitis C virus infection. Part 1. Sialadenitis and salivate glands lymphoma. Oral Dis 14: 123-130. 